\title{
Pollution, human health risk assessment and spatial distribution of toxic metals in urban soil of Yazd City, Iran
}

Somayeh Soltani-Gerdefaramarzi ( $\sim$ ssoltani@ardakan.ac.ir )

Ardakan University https://orcid.org/0000-0002-7806-2602

Mohsen Ghasemi

Ardakan University

Morteza Gheisouri

University of Tehran

\section{Original Research}

Keywords: Multivariate statistical analysis, Pollution indexes, Risk health assessment, Toxic metals, Urban soil.

Posted Date: February 9th, 2021

DOI: https://doi.org/10.21203/rs.3.rs-174408/v1

License: (c) (i) This work is licensed under a Creative Commons Attribution 4.0 International License. Read Full License

Version of Record: A version of this preprint was published at Environmental Geochemistry and Health on February 9th, 2021. See the published version at https://doi.org/10.1007/s10653-021-00844-y. 


\title{
Pollution, human health risk assessment and spatial distribution of toxic metals in urban soil of Yazd City, Iran
}

\author{
Somayeh Soltani-Gerdefaramarzi ${ }^{1 *}$, Mohsen Ghasemi ${ }^{2}$, Morteza Gheisouri ${ }^{3}$ \\ 1- Assistance Professor, Faculty of Agricalture and Natural Resource, Ardakan University, Ardakan, Iran. \\ Corresponding author, Email: ssoltani@ ardakan.ac.ir \\ 2- PhD of Water Sciences and Engineering, Faculty of Agricalture and Natural Resource, Ardakan \\ University, Ardakan, Iran. \\ 3- PhD Student, Faculty of Natural Resources, Tehran University, Tehran, Iran.
}

\begin{abstract}
Heavy metal pollution significantly reduces the quality of the environment and threatens human health especially in industrial cities. This study investigated toxic metals concentrations, pollution levels and human health risks assessment of urban soils in Yazd city, as an industrial city in center of Iran. Soil surface samples $(0-10 \mathrm{~cm})$ were collected from 30 points in the area for geochemical analysis. The concentrations of heavy metals were determined using an inductively coupled plasma mass spectrometry (ICP-MS).The values of the mean concentrations of toxic metals $\left(\mathrm{mg} \mathrm{kg}^{-1}\right)$ in the urban soils decrease in the order of $\mathrm{Zn}$ (83.9) > $\mathrm{Pb}(34.5)>\mathrm{Cr}(32.6)>\mathrm{Cu}(23.5)>\mathrm{Ni}(23.4)>\mathrm{As}(5.86)>\mathrm{Co}$ (4.86) > Cd (0.27). The mean concentration of $\mathrm{Zn}, \mathrm{Pb}$, As and $\mathrm{Cd}$ elements were higher than the background and the crust values. A pollution assessment by Geo-accumulation Index $\left(\mathrm{I}_{\mathrm{geo}}\right)$, Pollution Index (PI), Contamination Degree $\left(\mathrm{C}_{\mathrm{D}}\right)$, the Integrated Pollution Index (IPI), the Pollution Load Index (PLI) and Integrated Nemerow Pollution Index (INPI) showed that $\mathrm{As}, \mathrm{Cd}$ and $\mathrm{Pb}$ were moderately enriched and the study area polluted considerably by these toxic metals. Based on PI results, $88.9 \%$ of the urban soil samples highly polluted by As. Overall, the quality of the urban soil in Yazd city is clearly affected by toxic metals. Due to the prevailing wind direction, the route of the north-south highway of Iran and the population density and traffic of the northwestern and southern areas of the study area were found the highest level of pollution indicators (IPI $>1.8$; LPI $>1.3 ; \mathrm{C}_{\mathrm{D}}>15$ and $\mathrm{INPI}>4.3$ ). The results of Pearson correlation analysis indicated that all pollution evaluation indicators were influenced by $\mathrm{As}$ and $\mathrm{Cu}$, and showed high significant correlation with these two elements, while neither of them had a significant relationship with $\mathrm{Pb}$ and was found also a weak link statistically with Cd. Health Risk assessment of toxic metals has been performed in both carcinogenic and non-carcinogenic sectors. The results indicate that oral intake is the main pathway that toxic metals can harm human health for both the child and adults. The carcinogenic risks (RI) of adults and child by toxic metals were as follows: $\mathrm{Ni}>\mathrm{Pb}>\mathrm{Cr}>\mathrm{As}>\mathrm{Cd}$. Hazard quotients (HQ) and hazard index (HI) values for
\end{abstract}


child also were higher than these for adults. Generally, the results demonstrated that the potential carcinogenic health risks for adults of toxic metals was in an acceptable range in study area whereas for $\mathrm{Cr}$, $\mathrm{Ni}$ and $\mathrm{Pb}$ with $\mathrm{RI}>10^{-4}$, the risk of cancer in child probably increase.

Key words: Multivariate statistical analysis, Pollution indexes, Risk health assessment, Toxic metals, Urban soil.

\section{Introduction}

One of the most important problems threatening the health and food security of a society is environmental pollution and heavy metals production resources (Cai et al., 2012). The presence of heavy elements in soils depends on the natural evolution of the parent material or is due to human-source contamination. Soil contamination with heavy metals such as $\mathrm{Cd}, \mathrm{Cu}, \mathrm{Cr}, \mathrm{Pb}, \mathrm{Ni}$ and $\mathrm{Zn}$ in aridity ecosystems is known as a serious environmental health crisis. Soil is a source of nutrition for the biotic community and a buffer zone for environmental pollutants, and long-term entry of heavy metals into the soil can directly reduce soil buffering capacity, which adversely affects soil ecological performance due to inhibition of soil microbial activity (Tepanosyan et al., 2016; Pan et al., 2016; Wang et al., 2017). Due to their non-biodegradability and long detention time, these heavy metals tend to enter food chains and eventually accumulate in plant, animal and human tissues (Namuhani and Cyrus, 2015). It can accumulate in agricultural soils, leading to a gradual decrease in soil fertility, degradation of soil biology and reduced crop productivity (Zhao et al., 2014; Xu et al., 2017). Excessive consumption of heavy metals also causes acute and chronic poisoning such as damage to systems central nervous system, blood, lungs, kidneys, liver and even death (Wei et al., 2015). Over the past few decades, exposure to soil which enriched with heavy metals, has been widely examined in terms of pollution and their health problems. These investigations have been done either on urban soils (Imperato et al., 2003; Cai et al., 2012; Guo et al., 2012; Luo et al., 2015; Pan et al., 2018; Yang et al., 2020; Li et al., 2020), lake sediments (Bai et al., 2011; Liu et al., 2018; Bahloul et al., 2018; Xu et al., 2020), road dust (Charlesworth et al., 2003; Soltani et al., 2015; Dehghani et al., 2017; Xiao et al., 2019; Cui et al., 2020), stormwater runoff (Brown and Peake, 2006), agricultural soils (Agarwal et al., 2009; Baltas et al., 2020; Doabi et al., 2018) or in soils under different land use (Ma et al., 2020). Due to the fact that urban soils are mainly affected by the rapid expansion of urbanization, human activities, high city traffic and increase of industrial and agricultural activities near cities, this study focuses on pollution, health risk assessment and pollution indicators from Yazd urban soil in the center of Iran.

Investigating the ratio of heavy metals from human activities to the concentration of metals derived from natural sources, in the form of enrichment indicators and pollution factors, is one of the most common solutions for soil contaminants investigation (Franco et al., 2009). Higher than average background indicate human input sources in the region. Because of its possible damage to human health and the quality of the 
environment in urban areas, indicators such as potential Ecological Risk Index (RI), Contamination factor $\left(\mathrm{C}_{\mathrm{f}}\right)$, potential Ecological Risk factor (Er), Pollution load index (PLI), Enrichment factor (EF), Geoaccumulation index $\left(\mathrm{I}_{\mathrm{geo}}\right)$, Contamination degree $\left(\mathrm{C}_{\mathrm{d}}\right)$, Integrated pollution index (IPI), Integrated Nemerow Pollution Index (INPI), Pollution Index (PI), hazard index (HI), carcinogenic risk (RI) and hazard quotient (HQ) for health risk assessment and etc... have been calculated by some researchers broadly to assess soil contamination with heavy metals in recent decades. For example, Bartas et al., (2020) to investigate the pollution status and spatial distribution of heavy metals such as $\mathrm{Cr}, \mathrm{Fe}, \mathrm{Ni}, \mathrm{Cu}, \mathrm{Zn}, \mathrm{As}$ and $\mathrm{Pb}$ in soil around Sinop Province, Turkey, metal pollution parameters such as EF, $\mathrm{I}_{\mathrm{geo}}, \mathrm{CF}$, PLI and the human health risks model introduced by USEPA were applied. Their results suggested that child are slightly more sensitive to the non-carcinogenic and carcinogenic effects of metals than adults and the non-carcinogenic risk for child has not an acceptable risk to human health, but it was for adults. Yang et al., (2020) were used Contamination factor $\mathrm{C}_{\mathrm{f}}$, PLI, RI and potential ecological risk factor to assess the pollution degree of heavy metals in 0-10 and 10-20 cm soil depth from Linfen in China and showed the pollution from heavy metal is considerable; almost $50 \%$ of the study area were polluted and conclude that there was not observed significant differences between topsoil and subsoil samples and the concentration of toxic elements was higher than background values. Xiao et al., (2019) to determine comprehensively the contamination level and human health risk by trace elements in road dust of city Anshan, Northeast China calculated RI, PI, $\mathrm{I}_{\text {geo }}, \mathrm{RI}$ and HI. The $\mathrm{I}_{\text {geo }}$ and PI values of heavy metals were reduced in the following order: $\mathrm{Cd}>\mathrm{Sb}>\mathrm{Zn}>$ $\mathrm{Fe}>\mathrm{Pb}>\mathrm{Cu}>\mathrm{Cr}>\mathrm{Sn}>\mathrm{Mn}>\mathrm{Ni}$. Also, the $\mathrm{HI}$ showed a probability of non-carcinogenic risk for child in urban areas compared to adults.

Due to the greater sensitivity of children compared to adults to possible damage caused by heavy metals, in urban industrial areas such as Yazd, which has the main industries of tiles, ceramics and steel, It is necessary to determine the concentration and level of contamination of toxic metals and also to identify the hot spots of heavy metals in the study area. For this purpose, in present study, the pollution assessment indexes such as $\mathrm{I}_{\text {geo }}$, PI, LPI, IPI, $\mathrm{C}_{\mathrm{D}}$, INPI and Hazard index (HI), carcinogenic risk (RI) and hazard quotient (HQ) for health risk assessment indicators have been calculated to evaluate the degree of contamination and health risk assessment in both groups of child and adults in the urban soil of Yazd in central Iran. Also, Geographical Information System (GIS), inverse distance weighting method (IDW) was applied to zone the concentration of heavy metals or indexes in study area. The results of this study will quite suitable for planning, risk assessment, decision making by environmental managers and the policy makers of the municipality in this area.

\section{Materials and methods}

\section{- Study area}


Yazd province with an area of $131600 \mathrm{Km}^{2}$ located between $52^{\circ}$ and $55^{\prime}$ to $56^{\circ}$ and $37^{\prime}$ east longitude and $29^{\circ}$ and $52^{\prime}$ to $33^{\circ}$ and $27^{\prime}$ north latitude in the center of Iran. Yazd province is one of the driest and industrial regions in Iran, where the tile, ceramic, steel, textile industries and mining operations are developed significantly in recent years. Due to the natural location and geomorphological characteristics of the province, the precipitation varies from less than $50 \mathrm{~mm}$ in desert areas to more than $450 \mathrm{~mm}$. The main part of the province is a dry and semi-arid climate, which is characterized by low and irregular rainfall and humidity, extreme temperature fluctuations, high evaporation and hot and long periods (Sharifi et al., 2020). The Yazd city is the capital of the province with a population of 656474. Due to the industrialization of the city in the past twenty years, many immigrants from around Iran have migrated to this city, which has led to rapid urbanization growth. Yazd Industrial Town and Iran Alloy Steel Company are located in the west of the city with a distance of about 10 and $30 \mathrm{~km}$ from the city center and in the direction of prevailing winds. On the other hand, this city is located on the main north-south highway of Iran, which has high road traffic every year (Fig. 1). Considering the mentioned points, the concentration of toxic metals in the area is significantly predicted, and it seems necessary to study the concentration of these elements in the soil of urban areas and to examine the degree of their pollution.

(Fig. 1 here)

\section{- Soil sampling}

In winter 2019, 30 samples of topsoil (weighing approximately $500 \mathrm{~g}$ ) were collected from different places with suitable dispersion in Yazd city from a depth of 0-10 cm. Soil samples were collected close to airport, terminal, highways, as well as busy vehicle areas in the city center (Soltani et al., 2015). Each sample was collected by gentle sweeping of an area of about $400 \mathrm{~cm}^{2}$ using a hand-held plastic broom and transferred to a clean, self-packed polyethylene bag. In the laboratory, the samples are first dried at room temperature and then mechanically passed through a $2 \mathrm{~mm}$ sieve to separate waste particles and large sizes and plant leaves. The four-acid method has been used to digest soil samples in the study area. In this method, $0.25 \mathrm{~g}$ of soil samples passed through a mesh of 200, dried and prepared with D4698-92 standard (Pietilä et al., 2015; Amr et al., 2016) were heated in a mixture of acids $\mathrm{HF}-\mathrm{HNO}_{3}-\mathrm{HClO}_{4}$ and then the residual material is dissolved in HCL. The concentrations of heavy metals of the solution is digested in 4 acids (As, Cd, Co, $\mathrm{Cr}, \mathrm{Cu}, \mathrm{Ni}, \mathrm{Pb}$ and $\mathrm{Zn}$ ) were determined using an inductively coupled plasma mass spectrometry (ICP-MS, method, Perkin-Elmer, USA). Each soil sample was analyzed with three times and the mean values were obtained.

\section{- Statistical analysis}


Statistically significant differences between the mean of the toxic elements concentrations in the urban soil are tested using a one-way analysis of variance (ANOVA) followed by a post-hoc Duncan's test in SPSS package version 16.0 for Windows. Pearson's correlation analysis using a 2-tailed test of significance was performed to determine relationships among the considered variables and whether toxic metals may be from the similar source. The grouping of toxic metals in urban soil was implemented by Hierarchical Cluster analysis (HCA), Ward's method with Euclidean distances. Also, Geographical Information System (GIS), inverse distance weighting method (IDW) was used to distribute spatially the concentration of heavy metals or indexes in study area.

\section{- Health risk assessment}

Health Risk assessment of toxic metals is a multi-step process that has been performed in both carcinogenic and non-carcinogenic sectors based on the method of health risk assessment provided by the United States Environmental Protection Agency (USEPA). In the study of both carcinogenic and non-carcinogenic risks, human exposure to metals from all three pathways of ingestion, inhalation, and dermal contact were considered and the daily intake dose (ADD) in each of the pathways were calculated by using the Eqs. (13):

$A D D_{\text {ing }}=C \times \frac{\text { IngR } \times \mathrm{EF} \times \mathrm{ED}}{\mathrm{BW} \times \mathrm{AT}} \times 10^{-6}$

$A D D_{\text {inh }}=C \times \frac{\mathrm{InhR} \times \mathrm{EF} \times \mathrm{ED}}{\mathrm{PEF} \times \mathrm{BW} \times \mathrm{AT}}$

$A D D_{\text {dermal }}=C \times \frac{\mathrm{SL} \times \mathrm{SA} \times \mathrm{ABS} \times \mathrm{EF} \times \mathrm{ED}}{\mathrm{BW} \times \mathrm{AT}} \times 10^{-6}$

These three ways of exposure are often applied to evaluate the risk of metal exposure to human in urban areas (Pan et al., 2018). For the evaluation of the human health risk of urban soils polluted by toxic metals, the carcinogenic risk (RI), hazard index (HI) and hazard quotient (HQ) methods were used (Wei et al. 2015). The HQ was calculated by dividing the ADD for each exposure pathway by the reference dose (a metal's maximum daily dose from a special exposure route by attention to sensitive individuals during a life through both child and adults) using the Eqs. (4). The HI is the sum of the HQ values, which was calculated by using Eqs. (5). If HQ and HI are less than 1, it will not be found adverse health effects and while, HQ and HI > 1 indicate undesirable effects on human health (USEPA, 2001). The carcinogenic risk to health can be ignored if $\mathrm{RI}<10^{-6}$, whereas for $\mathrm{RI}>10^{-4}$ the risk of cancer in humans probably increase and values between $10^{-4}$ and $10^{-6}$ will lead to acceptable risk to human health (Hu et al., 2011; Xiao et al. 2019).

$H Q_{\mathrm{i}}=\frac{\mathrm{ADD}_{i}}{\operatorname{RfD}_{i}}$

$H I=\sum_{1}^{i} H Q_{\mathrm{i}}=H Q_{\text {ing }}+H Q_{\text {inh }}+H Q_{\text {dermal }}$ 
$\operatorname{Risk}(R I)=\sum A D D_{i} \times S F_{i}$

Where, $\mathrm{C}$ is the concentration of toxic metals urban soil in Equation (1)-(3). InhR is the inhalation rate. $\mathrm{EF}$ is the exposure frequency. $\mathrm{ED}$ is the exposure duration. SA is the exposed skin area. SL is the skin adherence factor. BW is the human body weight. ABS is the dermal absorption factor (unitless). PEF is the particle emission factor. AT is the average exposure time. RfD is the daily intake reference dose (Liu et al., 2018). SF is the development probability of cancer per unit exposure level of $\mathrm{mg} \mathrm{kg}^{-1}$ day. The values of those parameters were summarized in Table 1.

(Table 1 here)

\section{- Pollution indexes}

Heavy element pollution indexes are divided into two main groups. The first category of individual indicators are for assessing an element pollution. Some of them include the Geo-accumulation index $\left(\mathrm{I}_{\text {geo }}\right)$ and the Pollution Index (PI). The second category examines the pollution of more than one element and are integrated indicators. These include the Contamination Degree $\left(\mathrm{C}_{\mathrm{D}}\right)$, the Integrated Pollution Index (IPI), the Pollution Load Index (PLI) and Integrated Nemerow Pollution Index (INPI). In the present study, these indicators have been calculated and examined to evaluate the level of contamination of toxic metals in urban soils from Yazd city.

- Geo-accumulation index ( $\left.\mathrm{I}_{\text {geo }}\right)$

The $\mathrm{I}_{\text {geo }}$ is calculated using Equation (7) (Muller, 1969):

$I_{\text {geo }}=\log _{2}\left[\frac{C_{n}}{1.5 B_{n}}\right]$

Where $C_{n}$ is the measured concentration of the element in the soil sample and $B_{n}$ is the background concentration (soil or earth crust) of the same element (Wei et al., 2009; Chen et al., 2005). The Geoaccumulation index $\left(\mathrm{I}_{\text {geo }}\right)$ is assessed by dividing it into 7 categories as follow: class 1, Unpolluted (Igeo $\leq$ $0)$; class 2 , unpolluted to moderately polluted $(0<$ Igeo $<1)$; class 3 , moderately polluted $(1<$ Igeo $<2)$; class 4 , moderately to highly polluted $(2<$ Igeo $<3)$; class 5 , highly polluted $(3<$ Igeo $<4)$; class 6 , highly to very highly polluted ( $<$ Igeo < 5); and class 7, very highly polluted (Igeo $\geq 5$ ) (Gueguen et al., 2012).

\section{- $\quad$ pollution index $(\mathrm{PI})$}

The PI was calculated (Chen et al. 2005; Xiao et al. 2015):

$P I=\frac{C_{n}}{B_{n}}$

According to the value of PI, pollution index was calculated and dived into three classes as either low (PI $\leq 1)$, middle $(1<\mathrm{PI}<3)$, or high $(\mathrm{PI} \geq 3)$. 
- Pollution Load Index (PLI)

To investigate a sample's total contamination status, was calculated the Pollution Load Index (PLI) by the Equation (9) (Chen et al. 2015):

$P L I=\left(P I_{1} \times P I_{2} \times P I_{3} \times \ldots \times P I_{n}\right)^{\frac{1}{n}}$

Where $\mathrm{n}$ is the number of toxic elements analyzed. According to Chakravarty and Patgiri, (2009) scale, if

PLI $>1$, the study area is contaminated by metals, and if PLI $<1$, there is no contamination by metals in the area.

- Integrated pollution index (IPI)

The IPI is defined as the average amount of heavy metal PI (Chen et al., 2005) and then was categorized as low (IPI $\leq 1)$, middle $(1<\mathrm{IPI}<2)$, or high (IPI $\geq 2)$.

$I P I=\frac{\sum_{i=1}^{n} P I}{n}$

\section{- Contamination Degree $\left(\mathrm{C}_{\mathrm{D}}\right)$}

The Contamination Degree $\left(\mathrm{C}_{\mathrm{D}}\right)$ includes the total PI for each element (Nazzal et al., 2013) and are calculated from the following equation, and four classes of pollution are defined based on Contamination Degree $\left(C_{D}\right)$ as fallow: class 1 , low polluted $\left(C_{D}<5\right)$; class 2 , moderately polluted $\left(5 \leq C_{D}<10\right)$; class 3 , considerably polluted $\left(10 \leq \mathrm{C}_{\mathrm{D}}<20\right)$ and class 4 , highly polluted $\left(\mathrm{C}_{\mathrm{D}} \geq 20\right)$.

$C_{D}=\sum_{i=1}^{n} P I_{i}$

\section{- Integrated Nemerow Pollution Index (INPI)}

Considering all the toxic elements in the soil, the Integrated Nemerow Pollution Index (INPI) can be calculated based on Equation (12) for each sampling station (Niu et al., 2020).

$\mathrm{INPI}=\sqrt{\left(\mathrm{PI}_{\mathrm{ave}}\right)^{2}+\frac{\left(\mathrm{PI}_{\max }\right)^{2}}{2}}$

Where $\mathrm{PI}_{\text {ave }}$ and $\mathrm{PI}_{\max }$ are the mean value of the PI for all the toxic elements and the maximum value of PI among these 8 toxic elements. The level of pollution based on Integrated Nemerow Pollution Index (INPI) classified in the 5 pollution classes as follows: class 1, Unpolluted (INPI $<0.7$ ); class 2, moderately unpolluted $(0.7 \leq$ INPI $<1)$; class 3 , low polluted $(1 \leq$ INPI $<2)$, class 4 , moderately polluted $(2 \leq$ INPI $<$ 3 ) and class 4 , highly polluted (INPI $\geq 3$ ).

\section{Results and discussion}

\section{- Toxic elements concentration}


To compare the heavy metals contents in urban soil of Yazd city with reported values for other countries and cities also for background and crust values in previous studies, Table 2 is presented. The values of the mean concentrations of heavy metals $\left(\mathrm{mg} \mathrm{kg}^{-1}\right)$ in the urban soils decrease in the order of $\mathrm{Zn}(83.9)>\mathrm{Pb}$ (34.5) > $\mathrm{Cr}(32.6)>\mathrm{Cu}(23.5)>\mathrm{Ni}(23.4)>\mathrm{As}$ (5.86) > Co (4.86) > Cd (0.27). The mean concentration of $\mathrm{Zn}, \mathrm{Pb}, \mathrm{As}$ and $\mathrm{Cd}$ elements were higher than the background and crust values, while those of $\mathrm{Ni}$ and $\mathrm{Cu}$ elements were found more than the background values but less than the crust value. The elements of $\mathrm{Cr}$ and Co were also obtained less than both background and crust concentrations. Overall, the mean concentration of all toxic elements in Yazd is lower compared to its value in other cities except Kerman in Iran (Sistani et al., (2017), except for Pb in Damascus, Syria (Moller et al., (2005), Nickel in Guangzhou, China (Cai et al., (2012), Cu in Linfen, China (Yang et al., (2020), Cr in Naples, Italy (Imperatoa et al., (2003) and Cd in Guangzhou (Cai et al., (2012) and Varamin (Babaakbari et al., (2019) in Iran and As in Tehran (Dehghani et al., (2017), capital of Iran. Zhou et al., (2014) reported that in Huanghuai Plain, China, the amount of heavy metals is similar to or slightly higher than the background values in this area, with the exception of Cd, which averages almost twice the background value. Wang et al., (2017) stated that the mean concentrations of heavy metals in a typical industrial area in Sichuan were lower than the national threshold values, but were slightly higher than their corresponding background values. The Spatial distribution of the concentration of 8 toxic elements in the urban soil of Yazd city is illustrated in Fig. 2. As the results shows, the spatial variability pattern of $\mathrm{Co}, \mathrm{Cr}$, and $\mathrm{Ni}$ metals are similar, and the highest values of these toxic elements are found in the northern, northwestern, and eastern parts of the study area. This could be a reason for the possible similarity source of these elements in surface soil (Norouzi et al., 2017). Since the amount of these elements is less than the values of background and crust, they probably have a natural and geogenic source (Qing et al., 2015; Yang et al., 2020). The elements of $\mathrm{Cu}, \mathrm{Zn}$, and $\mathrm{Pb}$ follow a similar pattern and are most prevalent in the southern parts of the city, where the population density and traffic are high. De Miguel et al. (1997) suggested that heavy metals in the urban area could be classified as "urban" elements (e.g., $\mathrm{Cd}, \mathrm{Cu}, \mathrm{Pb}, \mathrm{Zn}$ ) and elements of a mixed source or which are affected by geochemical changes from their original sources (e.g., $\mathrm{Cr}, \mathrm{Ni}$ ). Moreover, many authors suggested that enrichment of $\mathrm{Cu}, \mathrm{Zn}$, and $\mathrm{Pb}$ in the urban soils deriving from main anthropogenic source (Lee et al. 2006; Yang et al., 2020).

(Table 2 here)

(Fig. 2 here)

\section{Contamination levels of toxic elements}

- Geo-accumulation index ( $\left.\mathrm{I}_{\text {geo }}\right)$

Calculated Geo-accumulation index ( $\left.\mathrm{I}_{\text {geo }}\right)$ values in the urban soils of Yazd City are summarized in the Table 4. Also, the spatial distribution maps of Geo-accumulation index ( $\mathrm{I}_{\mathrm{geo}}$ ) values of toxic metals are presented in Fig. 3. $I_{\text {geo }}$ values were illuminated with the background concentration of earth crust defined 
by McLennan (2001). The average $\mathrm{I}_{\mathrm{geo}}$ values of the toxic metals were found in the order of As (1.36) $>\mathrm{Cd}$ $(0.89)>\mathrm{Pb}(0.42)>\mathrm{Zn}(-0.36)>\mathrm{Cu}(-0.7)>\mathrm{Ni}(-1.54)>\mathrm{Cr}(-1.97)>\mathrm{Co}(-2.43)$. For other toxic metals, except $\mathrm{As}, \mathrm{Cd}$ and $\mathrm{Pb}$, the average $\mathrm{I}_{\text {geo }}$ index was found to be smaller than 0 . According to the Müller scale, the index of $\mathrm{I}_{\text {geo }}$ indexes in the study area is not polluted with $\mathrm{Zn}, \mathrm{Ni}, \mathrm{Cu}, \mathrm{Cr}$ and $\mathrm{Co}$, unpolluted to moderately polluted with $\mathrm{Cd}$ and $\mathrm{Pb}$ and moderately polluted with As. The results of researchers in other parts of the world are different, for example the mean $I_{\text {geo }}$ trend for heavy elements in soils of industrial estate, Pakistan were $\mathrm{Cr}>\mathrm{Pb}>\mathrm{Cu}>\mathrm{Zn}>\mathrm{Fe}>\mathrm{Mn}>\mathrm{Co}>\mathrm{Ni}>\mathrm{Cd}$ (Hussain et al., 2015). Wang et al., (2017) point out the $\mathrm{I}_{\text {geo }}$ values of heavy metals in Sichuan showed the order of $\mathrm{Cu}>\mathrm{Zn}>\mathrm{Cr}>\mathrm{Hg}>\mathrm{Cd}>\mathrm{As}$. The average $\mathrm{I}_{\text {geo }}$ values of the heavy metals were found in the order of $\mathrm{As}>\mathrm{Cr}>\mathrm{Pb}>\mathrm{Zn}>\mathrm{Ni}>\mathrm{Cu}>\mathrm{Fe}$ in Turkey (Baltas et al., (2020). The results are variable in terms of type and amount of pollution, land use or the presence of various pollution sources due to different conditions of the studied areas.

(Table 4 here)

(Fig. 3 here)

\section{- $\quad$ Pollution Index (PI)}

Box-plots and the characteristics of PI for toxic metals in the urban soil samples of Yazd indicated in Fig. 4 and Fig. 5. According to the results of this index, the elements of $\mathrm{Cu}$ (from 0.64 to 1.32 with a mean of 0.94 ), $\mathrm{Ni}$ (from 0.32 to 0.82 with a mean of 0.53 ), $\mathrm{Cr}$ (from 0.25 to 0.66 with a mean of 0.39 ) and Co

(from 0.18 to 0.44 with a mean of 0.28 ) indicated low PIs in the urban soils, showing that the concentrations of $\mathrm{Cu}, \mathrm{Ni}, \mathrm{Cr}$ and $\mathrm{Co}$ in the urban soil samples were comparable with the earth crust values of toxic metals in soils and there was no clear pollution of $\mathrm{Cu}, \mathrm{Ni}, \mathrm{Cr}$ and $\mathrm{Co}$, however $61.1 \%$ and $38.9 \%$ of soil samples were classified as low PIs and moderately polluted for $\mathrm{Cu}$, respectively, as well $100 \%$ of them were categorized as low PIs for Ni, Cr and Co. Middle PIs was found for Cd (from 2.04 to 4.08 with a mean of 2.83) with $72.2 \%$ and $27.8 \%$ of soil samples were determined as moderately and high polluted respectively, $\mathrm{Pb}$ (from 1.58 to 2.41 with a mean of 2.03) with $100 \%$ of samples, and $\mathrm{Zn}$ (from 0.97 to 1.65

with a mean of 1.18 ) with $88.9 \%$ of the urban soils, whereas the PIs of As were considerably higher, varying from 2.6 to 5.6 with a mean of 3.91 ; were classified with $88.9 \%$ of samples as highly polluted. In the soils of Yibin City, China Guo et al., (2014) reported the PI value of As ranged from 0.24 to 1.93, with a mean value of 0.86 , The $\mathrm{PI}$ value of $\mathrm{Pb}$ ranged from 0.66 to 7.24, The PI value of $\mathrm{Zn}$ varied from 0.42 to 4.19 with a mean value of 1.61 , The PI of $\mathrm{Cu}$ was in the range of $0.62-5.25$, with a mean value of

\subsection{8. (Fig. 4 here)}

(Fig. 5 here)

- $\quad$ IPI, PLI, INPI and $\mathrm{C}_{\mathrm{D}}$ 
The IPIs of eight toxic elements in urban soil samples varied from 1.32 to 1.90 with a mean of 1.51 (Fig. 6) and was classified as moderate pollution. It was clear that the high IPI in most of soil samples was mainly considered by $\mathrm{As}, \mathrm{Pb}$ and $\mathrm{Cd}$ values. IPI values of these metals varied from 0.82 to 3.54, with a mean of 1.6 in urban soils from southwest China (Guo et al., 2014). The minimum, maximum, and mean values of PLI were 0.96, 158.2, and 21.8, respectively in Pakistan (Hussain et al., 2015). As well as, PLI was found to change from 0.82 to 1.38 with a mean of 1.04 and about of $33 \%$ of soil samples exhibited no contamination (Fig. 7). A previous study in Turkey by Baltas et al., (2020) showed that the average PLI value was found to be 1.18. The Contamination Degree $\left(C_{D}\right)$ or the total PI for each element in urban soils ranged from minimum 10.59 to maximum 15.19 with a mean of 12.11 , as a results the study area was found as considerably polluted. The mean of the INPI index calculated in 30 stations ranged from 2.57 to 4.39 with a mean of 3.18 and the standard deviation was equal to 0.48 , values which $39 \%$ of stations fall within the medium pollution class (Category 4 ) and $61 \%$ of them showed high pollution (Category 5). The high NPI value ranged from 0.90 to 3.55 with a mean value of 1.65 , indicating moderate pollution by the heavy metals in Sichuan (Wang et al., 2017). Overall, the quality of the urban soil in Yazd city is clearly affected by toxic metals. The highest values of pollution indicators (IPI > 1.8; LPI > 1.3; $\mathrm{C}_{\mathrm{D}}>15$ and INPI $>4.3$ ) were found in the northwestern areas (the area closest to the main highway) and the south of the study area (the area with high population density and high traffic).

(Fig. 6 here)

(Fig. 7 here)

\section{Human health risk assessment of toxic elements}

- Carcinogenic and Non-carcinogenic risk assessment

Human health risk evaluation methods have been used to assess the risk to child and adults. Table 3 shows the health risk assessment results due to exposure to toxic metals in the urban soils in Yazd city. The mean $\mathrm{HQ}_{\text {ing }}$ values $\mathrm{As}, \mathrm{Cd}, \mathrm{Cr}, \mathrm{Cu}, \mathrm{Ni}, \mathrm{Pb}$ and $\mathrm{Zn}$ were 2.50E-01, 1.19E-03, 1.39E-01, 7.52E-03, 1.50E-02, 1.26E01 and 3.58E-03 for child and were 3.36E-02, 1.59E-04, 1.87E-02, 1.01E-03, 2.02E-03, 1.70E-02 and 4.81E-04 for adults respectively. The mean HQ values by inhalation for child found 6.79E-06, 3.32E-08, 4.09E-04, 2.10E-07, 4.08E-07, 3.52E-06 and 1.00E-07 while for adults were obtained 3.06E-06, 1.49E-08, 1.84E-04, 9.44E-08, 1.84E-07, 1.58E-06 and 4.52E-08 respectively. Also, the mean $\mathrm{HQ}_{\text {derm }}$ values As, Cd, $\mathrm{Cr}, \mathrm{Cu}, \mathrm{Ni}, \mathrm{Pb}$ and $\mathrm{Zn}$ were calculated 9.78E-04, 5.69E-04, 1.11E-02, 4.01E-05, 8.90E-05, 1.35E-03 and 2.87E-05 for child while were 2.49E-04, 1.45E-04, 2.84E-03, 1.02E-05, 2.27E-05, 3.43E-04 and 7.30E-06 for adults respectively. As the results suggested, Three-pathway exposure to metals for both child and adults have decreased in the form of $\mathrm{HQ}_{\text {ing }}>\mathrm{HQ}_{\text {inh }}>\mathrm{HQ}_{\text {derm. }}$. The results indicate that oral intake is the main pathway that toxic metals can harm human health for both the child and adults. Also, the ranking of $\mathrm{HQ}_{\text {ing }}$ 
$\mathrm{HQ}_{\text {inh }}$ and $\mathrm{HQ}_{\text {derm }}$ levels of child and adults by toxic metals were respectively as follows: $\mathrm{As}>\mathrm{Cr}>\mathrm{Pb}>$ $\mathrm{Ni}>\mathrm{Cu}>\mathrm{Zn}>\mathrm{Cd}$; $\mathrm{Cr}>\mathrm{As}>\mathrm{Pb}>\mathrm{Ni}>\mathrm{Cu}>\mathrm{Zn}>\mathrm{Cd}$ and $\mathrm{Cr}>\mathrm{Pb}>\mathrm{As}>\mathrm{Cd}>\mathrm{Ni}>\mathrm{Cu}>\mathrm{Zn}$ respectively. Of course, it should be noted that HQs and HI values for child also were higher than these for adults. HI of toxic metals' values for child decreased as: $\mathrm{As}>\mathrm{Cr}>\mathrm{Pb}>\mathrm{Ni}>\mathrm{Cd}>\mathrm{Cu}>\mathrm{Zn}>\mathrm{Cd}$ while with a slight change ranked for adults as: $\mathrm{Cr}>\mathrm{As}>\mathrm{Pb}>\mathrm{Ni}>\mathrm{Cd}>\mathrm{Cu}>\mathrm{Zn}>\mathrm{Cd}$. All HI values of toxic metals were less than 1 . This suggests that there are no non-carcinogenic risk for child and adults in study area. Wei et al. (2015) and Xiao et al., (2019) also reported that compared with the non-carcinogenic health risk for child, such risk for adults was lower. Furthermore, the carcinogenic risks (RI) and the total carcinogenic risks (TRI) for $\mathrm{As}, \mathrm{Cd}, \mathrm{Cr}, \mathrm{Ni}$ and $\mathrm{Pb}$ were evaluated and are presented in Table 3. According to results, the carcinogenic risk (RI) values were relatively higher for child than that for adults. Similar results were obtained by Zheng et al. (2010), Dehghani et al., (2017) Baltas et al., (2020) and Ma et al., (2020). Their research showed that the non-carcinogenic risk for children was above the threshold level, but low for adults. This suggests that child may be at greater risk for toxic metals in urban soil because child are most likely to have oral intake by hand and mouth (Kusin et al., 2018). As shown in Table 3, RI values were 1.53E-06 (As), 3.02E-07 (Cd), 2.36E-05 (Cr), 3.40E-05(Ni) and 2.50E-05 (Pb) for adults and were found 1.14E-05 (As), 2.24E-06 (Cd), 1.76E-04 (Cr), 2.52E-04 (Ni) and 1.86E-04 (Pb) for child. The RI ranged between 2.24E-06 to 2.52E-04 for child and between 2.36E-05 to 3.02E-07 for adults. RI of Adults and Child by toxic metals were as follows: $\mathrm{Ni}>\mathrm{Pb}>\mathrm{Cr}>\mathrm{As}>\mathrm{Cd}$. The total carcinogenic risks (TRI) of the toxic metals for adults and child was $8.44 \mathrm{E}-05$ and $6.28 \mathrm{E}-04$, respectively. Generally, the results demonstrated that the potential carcinogenic health risks for adults of toxic metals was in an acceptable range $\left(10^{-6}\right.$ to $\left.10^{-4}\right)$ in the urban soils in study area whereas for $\mathrm{Cr}$, $\mathrm{Ni}$ and $\mathrm{Pb}$ with $\mathrm{RI}>10^{-4}$, the risk of cancer in child probably increase. However, Soltani et al., (2015) reported that Isfahan residents in the neighborhood of the study area, are potentially exposed to high cancer risk via both dust ingestion and dermal contact.

(Table 3 here)

\section{- Multivariate statistical analysis}

Pearson correlation analysis and Hierarchical Cluster analysis (HCA) as effective tools were applied to determine the common relationship of soil elements that may indicate a similarity in source (Yang et al., 2018; Tholkappian et al. 2018; Yang et al., 2020). Pearson correlation coefficient between soil toxic metals and pollution indexes from urban soils presented in Table 5. As can be seen, significant positive correlations were found at the 0.01 level between As and $\mathrm{Co}$ (0.854), As and $\mathrm{Cr}(0.869)$, As and $\mathrm{Cu}(0.641)$, As and $\mathrm{Ni}$ (0.889); $\mathrm{Co}$ and $\mathrm{Cr}$ (0.961), Co and $\mathrm{Ni}$ (0.943); $\mathrm{Cr}$ and $\mathrm{Ni}$ (0.947); and $\mathrm{Pb}$ with $\mathrm{Zn}$ (0.597); but at the 0.05 level, $\mathrm{Cd}$ and $\mathrm{Pb}$ (0.527), $\mathrm{Cd}$ and $\mathrm{Zn}(0.558)$. While significant association negatively was observed between 
$\mathrm{Pb}$ and $\mathrm{Co}$ (-0.630), $\mathrm{Pb}$ and $\mathrm{Ni}(-0.604)$ and $\mathrm{Pb}$ with $\mathrm{Cr}$ (-0.514). Like many previous studies that have shown a strong positive correlation between toxic metals as a reason for their common source (Jaffar et al., 2017; Yang et al., 2020), the results of this study suggest a common and anthropogenic source for some toxic metals. $\mathrm{Cr}, \mathrm{Co}$, and $\mathrm{Ni}$, as mentioned earlier, had a negative $\mathrm{I}_{\mathrm{geo}}$, and based on the results of correlation analysis, they also have the strongest correlation (>0.94) and probably have a common natural and geological source. In the next rank, $\mathrm{Pb}$ and $\mathrm{Zn}$ showed the most positive link, and according to the results of the Geo-accumulation index, they probably have a similar anthropogenic source such as coal burning, iron and steel production, vehicle transport emissions and industrial activities (Lu et al., 2010; Schleicher et al., 2011). All pollution evaluation indicators were influenced by $\mathrm{As}$ and $\mathrm{Cu}$, and showed high significant correlation with these two elements, while neither of them had a significant relationship with $\mathrm{Pb}$. There was found also a weak correlation statistically with $\mathrm{Cd}$ and $\mathrm{Zn}$. Further, to explore the potential contamination source, was conducted Hierarchical Cluster analysis (HCA), Ward's method with Euclidean distances. Dendrogram of hierarchical cluster analysis for toxic metals from Yazd city with the influential variables on soil pollution ( $\mathrm{As}, \mathrm{Cd}, \mathrm{Cu}, \mathrm{Pb}$ and $\mathrm{Zn}$ ) are shown in Fig. 8. Three elements (Co, Cr, Ni) with $\mathrm{I}_{\text {geo }}$ lower than 0 (Probably the same natural and geogenic origin) were removed from cluster analysis to decrease the number of variables to the effective parameters. According to the results, three clusters in urban soils were distinguished. The first category was determined for the toxic metals $\mathrm{As}$ and $\mathrm{Cd}$. Toxic metals $\mathrm{Cu}$ and $\mathrm{Pb}$ were clustered at similar Euclidian distances, suggesting a probably same origin. $\mathrm{Zn}$ did not cluster with any of the other toxic metals, probably $\mathrm{Zn}$ came from different sources.

(Table 5 here)

(Fig. 8 here)

\section{Conclusion}

The concentrations, contamination levels, and health risks assessment of toxic metals (As, $\mathrm{Cd}, \mathrm{Cr}, \mathrm{Co}, \mathrm{Zn}$, $\mathrm{Cu}, \mathrm{Pb}$ and $\mathrm{Ni}$ ) in urban soils from Yazd city were studied. Results showed that for other toxic metals, except $\mathrm{As}, \mathrm{Cd}$ and $\mathrm{Pb}$, the average of the geo-accumulation index ( $\mathrm{I}_{\mathrm{geo}}$ ) was found to be smaller than 0 . According to the Müller scale, the index of $\mathrm{I}_{\text {geo }}$ indexes in the study area is not polluted with $\mathrm{Zn}, \mathrm{Ni}, \mathrm{Cu}, \mathrm{Cr}$ and $\mathrm{Co}$, unpolluted to moderately polluted with $\mathrm{Cd}$ and $\mathrm{Pb}$ and moderately polluted with As. Based on Pollution Index (PI), the concentrations of $\mathrm{Cu}, \mathrm{Ni}, \mathrm{Cr}$ and $\mathrm{Co}$ in the urban soil samples were comparable with the earth crust values of toxic metals in soils and there was no clear pollution of $\mathrm{Cu}, \mathrm{Ni}, \mathrm{Cr}$ and $\mathrm{Co}$. Middle PIs was found for $\mathrm{Cd}, \mathrm{Pb}$ and $\mathrm{Zn}$, whereas the PIs of As were considerably higher, were classified with $88.9 \%$ of samples as highly polluted. LPI was found to change from 0.82 to 1.38 with a mean of 1.04 and about of $33 \%$ of urban soil samples exhibited no contamination while the Contamination Degree $\left(\mathrm{C}_{\mathrm{D}}\right)$ in urban soils resulted as considerably polluted. Further, according to the results of Integrated Nemerow 
Pollution Index (INPI), 61\% of stations showed high pollution. The results of health risk analysis suggest that three-pathway exposure to metals for both child and adults have decreased in the form of $\mathrm{HQ}_{\text {ing }}>\mathrm{HQ}_{\text {inh }}$ $>\mathrm{HQ}_{\mathrm{derm}}$. HQs and $\mathrm{HI}$ values for child also were higher than these for adults. Also, the potential carcinogenic health risks for adults of toxic metals was in an acceptable range whereas for $\mathrm{Cr}, \mathrm{Ni}$ and $\mathrm{Pb}$, the risk of cancer in child probably increase in study area. According to the level of pollution in the study area and the risk of carcinogenic risk for children, it is necessary to provide and implement appropriate management strategies to reduce toxic metals pollution in the area.

\section{Acknowledgments}

This work was supported by Iran National Science Foundation (INSF) and the authors greatly appreciate a research productivity fellowship from INSF, (No. 96007731).

\section{Declaration of interests}

The authors declare that they have no known competing financial interests or personal relationships that could have appeared to influence the work reported in this paper.

\section{Reference}

Agarwal, T., Khillare, P. S., Shridhar, V., Ray, S., 2009. Pattern, sources and toxic potential of PAHs in the agricultural soils of Delhi, India. J Hazard Mater, 163:1033-9.

Alloway, B., 2010. Heavy Metals in Soils: Trace metals and metalloids in soils and their bioavailability, third ed. Springer publications, pp. 614.

Amr, M. A., Helal, A. F. I., Al-Kinani, A. T., Balakrishnan, P., 2016. Ultra-trace determination of 90Sr, $137 \mathrm{Cs}, 238 \mathrm{Pu}, 239 \mathrm{Pu}$, and $240 \mathrm{Pu}$ by triple quadruple collision/reaction cell-ICP-MS/MS: Establishing a baseline for global fallout in Qatar soil and sediments. Journal of environmental radioactivity, 153, 73-87.

Babaakbari, M., Shakori, M., Hasani, A., Seilspour, M., 2019. Assessing Pollution Risk of Heavy Metals in some of Varamin Agricultural Soils. Applied Soil Research, 7(3):14-24. (In Farsi)

Baltas, H., Sirin, M., Gökbayrak, E. and Ozcelik, A.E., 2020. A case study on pollution and a human health risk assessment of heavy metals in agricultural soils around Sinop province, Turkey. Chemosphere, 241, p.125015.

Brown, J. N., Peake, B. M., 2006. Sources of heavy metals and polycyclic aromatic hydrocarbons in urban stormwater runoff. Sci Total Environ, 359:145-55.

Bahloul, M., Baati, H., Amdouni, R., Azri, C., 2018. Assessment of heavy metals contamination and their potential toxicity in the surface sediments of Sfax Solar Saltern, Tunisia. Environ. Earth Sci. 77: 27. 
Bai, J., Cui, B., Chen, B., Zhang, K., Deng, W., Gao, H., Xiao, R., 2011. Spatial distribution and ecological risk assessment of heavy metals in surface sediments from a typical plateau lake wetland, China. Ecol. Model. 222, 301-306.

Cai, Q. Y., Mo, C. H., Li, H. Q., Lü, H., Zeng, Q. Y., Li, Y. W., Wu, X. L., 2012. Heavy metal contamination of urban soils and dusts in Guangzhou, South China. Environmental monitoring and assessment, 185(2), 1095-1106.

Cui, X., Wang, X. and Liu, B., 2020. The characteristics of heavy metal pollution in surface dust in Tangshan, a heavily industrialized city in North China, and an assessment of associated health risks. Journal of Geochemical Exploration, 210:106432.

Charlesworth, S., Everett, M., McCarthy, R., Ordóñez, A., de Miguel, E. A., 2003. Comparative study of heavy metal concentration and distribution in deposited street dusts in a large and a small urban area: Birmingham and Coventry, West Midlands, UK. Environ Int; 29: 563-73.

Chakravarty, M., Patgiri, A.D., 2009. Metal pollution assessment in sediments of the Dikrong River, NE India. J. Hum. Ecol. 27, $63 \mathrm{e} 67$.

Chen, T. B., Zheng, Y. M., Lei, M., Huang, Z. C., Wu, H. T., Chen, H., 2005. Assessment of heavy metal pollution in surface soils of urban parks in Beijing, China. Chemosphere, 60, 542-551.

Dehghani, S., Moore, F., Keshavarzi, B., Hale, B. A., 2017. Health risk implications of potentially toxic metals in street dust and surface soil of Tehran, Iran. Ecotoxicology and Environmental Safety. 136: 92103.

De Miguel, E., Llmas, J. F., Chacón, E., Berg, T., Larssen, S., Røyset, O., 1997. Origin and patterns of distribution of trace elements in street dust: Unleaded petrol and urban lead. Atmospheric Environment, 31, 2733-2740.

Doabi, S.A., Karami, M., Afyuni, M. and Yeganeh, M., 2018. Pollution and health risk assessment of heavy metals in agricultural soil, atmospheric dust and major food crops in Kermanshah province, Iran. Ecotoxicology and environmental safety, 163:153-164.

Franco-Uria, A., Lopez-Mateo, C., Roca, E., Fernandez-Marcos, M. L., 2009. Source identification of heavy metals in pastureland by multivariate analysis in NW Spain. Journal of Hazardous Materials, 165: 1008-1015.

Gueguen, F., Stille, P., Geagea, M.L., Boutin, R., 2012. Atmospheric pollution in an urban environment by tree bark biomonitoring-Part I: Trace element analysis. Chemosphere, 86(10): 1013-1019.

Guo, G., Wu, F., Xie, F. and Zhang, R., 2012. Spatial distribution and pollution assessment of heavy metals in urban soils from southwest China. Journal of Environmental Sciences, 24(3): 410-418. 
Hou, S., Zheng, N., Tang, L., Ji, X., Li, Y. and Hua, X., 2019. Pollution characteristics, sources, and health risk assessment of human exposure to $\mathrm{Cu}, \mathrm{Zn}, \mathrm{Cd}$ and $\mathrm{Pb}$ pollution in urban street dust across China between 2009 and 2018. Environment international, 128: 430-437.

Hu, X., Zhang, Y., Luo, J., Wang, T., Lian, H., Ding, Z., 2011. Bioaccessibility and health risk of arsenic, mercury and other metals in urban street dusts from a mega-city, Nanjing, China. Environ Pollut, 159: $1215-21$.

Hussain, R., Khattak, S.A., Shah, M.T. and Ali, L., 2015. Multistatistical approaches for environmental geochemical assessment of pollutants in soils of Gadoon Amazai Industrial Estate, Pakistan. Journal of Soils and Sediments, 15(5), pp.1119-1129.

Imperato, M., Adamo, P., Naimo, D., Arienzo, M., Stanzione, D. and Violante, P., 2003. Spatial distribution of heavy metals in urban soils of Naples city (Italy). Environmental pollution, 124(2): 247-256.

Jaffar, S.T.A., Luo, F., Ye, R., Younas, H., Hu, X.F. and Chen, L.Z., 2017. The extent of heavy metal pollution and their potential health risk in topsoils of the massively urbanized district of Shanghai. Archives of environmental contamination and toxicology, 73(3): 362-376.

Kusin, F.M., Azani, N.N.M., Hasan, S.N.M.S. and Sulong, N.A., 2018. Distribution of heavy metals and metalloid in surface sediments of heavily-mined area for bauxite ore in Pengerang, Malaysia and associated risk assessment. Catena, 165:454-464.

Lee, C. S., Li, X., Shi, W., Cheung, S. C., Thornton, I., 2006. Metal contamination in urban, suburban, and country park soils of Hong Kong: A study based on GIS and multivariate statistics. Science of Total Environment, 356: 45-61.

Li, Y., Yuan, Y., Sun, C., Sun, T., Liu, X., Li, J., Fang, L. and Fan, Z., 2020. Heavy metals in soil of an urban industrial zone in a metropolis: risk assessment and source apportionment. Stochastic Environmental Research and Risk Assessment, pp.1-12.

Liu, R., Bao, K., Yao, S., Yang, F. and Wang, X., 2018. Ecological risk assessment and distribution of potentially harmful trace elements in lake sediments of Songnen Plain, NE China. Ecotoxicology and environmental safety, 163: 117-124.

Lu, X., Wang, L., Li, L.Y., Lei, K., Huang, L., Kang, D., 2010. Multivariate statistical analysis of heavy metals in street dust of Baoji, NW China. Journal of hazardous materials, 173(1-3), pp.744-749.

Luo, X. S., Xue, Y., Wang, Y. L., Cang, L., Xu, B., Ding, J., 2015. Source identification and apportionment of heavy metals in urban soil profiles. Chemosphere, 127, pp.152-157.

Ma, L., Xiao, T., Ning, Z., Liu, Y., Chen, H. and Peng, J., 2020. Pollution and health risk assessment of toxic metal (loid) $\mathrm{s}$ in soils under different land use in sulphide mineralized areas. Science of The Total Environment, p.138176. 
McLennan, S.M., 2001. Relationships between the trace element composition of sedimentary rocks and upper continental crust. Geochemistry, Geophysics, Geosystems, 2(4):1-24.

Möller, A., Müller, H.W., Abdullah, A., Abdelgawad, G. and Utermann, J., 2005. Urban soil pollution in Damascus, Syria: concentrations and patterns of heavy metals in the soils of the Damascus Ghouta. Geoderma, 124(1-2), pp.63-71.

Muller, G., 1969. Index of geoaccumulation in sediments of the Rhine River. Geojournal, 2, 108-118.

Namuhani, N., Cyrus, K., 2015. Soil Contamination with Heavy Metals around Jinja Steel Rolling Mills in Jinja Municipality, Uganda. Journal of Health and Pollution, 5(9): 61-67.

Nazzal, Y., Rosen, M.A. and Al-Rawabdeh, A.M., 2013. Assessment of metal pollution in urban road dusts from selected highways of the Greater Toronto Area in Canada. Environmental monitoring and assessment, 185(2): 1847-1858.

Niu, A., Ma, J., Gao, Y., Xu, S. and Lin, C., 2020. Mangrove Soil-Borne Trace Elements in Qi'ao Island: Implications for Understanding Terrestrial Input of Trace Elements into Part of the Pearl River Estuary. Applied Sciences, 10(7): p.2439.

Norouzi, S., Khademi, H., Ayoubi, S., Cano, A.F. and Acosta, J.A., 2017. Seasonal and spatial variations in dust deposition rate and concentrations of dust-borne heavy metals, a case study from Isfahan, central Iran. Atmospheric Pollution Research, 8(4): 686-699.

Pietilä, H., Perämäki, P., Piispanen, J., Starr, M., Nieminen, T., Kantola, M., Ukonmaanaho, L., 2015. Determination of low methylmercury concentrations in peat soil samples by isotope dilution GC-ICPMS using distillation and solvent extraction methods. Chemosphere, 124, 47-53.

Qiang, L., Yang, W., Jingshuang, L., Quanying, W. and Mingying, Z., 2015. Grain-size distribution and heavy metal contamination of road dusts in urban parks and squares in Changchun, China. Environmental geochemistry and health, 37(1), 71-82.

Schleicher, N. J., S. Norra, F. Chai, Y. Chen, S. Wang, K. Cen, Y. Yu and D. Stuben. 2011. Temporal variability of trace metal mobility of urban particulate matter from Beijing- A contribution to health impact assessments of aerosols. Atmos. Environ. 45:7248-7265.

Sharifi, A., Soltani Gerdefaramarzi, S., Taghizadeh, R., Yarmi, N., 2020. Investigating the spatial variations of drought indices and their effect on soil salinity in Yazd-Ardakan Plain. Desert Ecosystem Engineering Journal, 9(27): 1-12. (In Farsi)

Sistani, N., Moeinaddini, M., Khorasani, N., Hamidian, A. H., Ali-Taleshi, M. S., Azimi Yancheshmeh. R., 2017. Heavy metal pollution in soils nearby Kerman steel industry: metal richness and degree of contamination assessment. Iranian Journal of Health and Environment. 10(1):75-86. 
Soltani, N., Keshavarzi, B., Moore, F., Tavakol, T., Lahijanzadeh, A.R., Jaafarzadeh, N., Kermani, M., 2015. Ecological and human health hazards of heavy metals and polycyclic aromatic hydrocarbons (PAHs) in road dust of Isfahan metropolis, Iran. Science of the Total Environment, 505:712-723.

Tepanosyan, G., Sahakyan, L., Belyaeva, O., Saghatelyan, A., 2016. Origin identification and potential ecological risk assessment of potentially toxic inorganic elements in the topsoil of the city of Yerevan, Armenia. J Geochem Explor 167:1-11.

Tholkappian, M., Ravisankar, R., Chandrasekaran, A., Jebakumar, J.P.P., Kanagasabapathy, K.V., Prasad, M.V.R., Satapathy, K.K., 2018. Assessing heavy metal toxicity in sediments of Chennai Coast of Tamil Nadu using Energy Dispersive X-Ray Fluorescence Spectroscopy (EDXRF) with statistical approach. Toxicol. rep 5, 173e182.

USEPA 1989. Risk Assessment Guidance for Superfund, Vol. I: Human Health Evaluation Manual. USEPA, Washington DC.

USEPA, 2001. Risk Assessment Guidance for Superfund: Volume III-Part A, Process for Conducting Probabilistic Risk Assessment Office of Emergency and Remedial Response. U.S. Environmental Protection Agency, Washington, D.C.

Pan, L., Ma, J., Wang, X., Hou, H., 2016. Heavy metals in soils from a typical county in Shanxi Province, China: levels, sources and spatial distribution. Chemosphere 148:248-254.

Pan, L., Wang, Y., Ma, J., Hu, Y., Su, B., Fang, G., Wang, L. and Xiang, B., 2018. A review of heavy metal pollution levels and health risk assessment of urban soils in Chinese cities. Environmental Science and Pollution Research, 25(2):1055-1069.

Wang, G., Zhang, S., Xiao, L., Zhong, Q., Li, L., Xu, G., Deng, O. and Pu, Y., 2017. Heavy metals in soils from a typical industrial area in Sichuan, China: spatial distribution, source identification, and ecological risk assessment. Environmental Science and Pollution Research, 24(20): 16618-16630.

Wei, B., Jiang, F., Li, X., Mu, S., 2009. Spatial distribution and contamination assessment of heavy metals in urban road dusts from Urumqi, NW China. Microchemical Journal, 93(2):147-152

Wei, X., Gao, B., Wang, P., Zhou, H., Lu, J., 2015. Pollution characteristics and health risk assessment of heavy metals in street dusts from different functional areas in Beijing, China. Ecotoxicology and environmental safety, 112: 186-192.

Xiao, Q, Zong, Y. T., Lu, S. G., 2015. Assessment of heavy metal pollution and human health risk in urban soils of steel industrial city (Anshan), Liaoning, Northeast China. Ecotox Environ Safe 120:377-85.

Xiao, Q., Zong, Y., Malik, Z., Lu, S., 2019. Source identification and risk assessment of heavy metals in road dust of steel industrial city (Anshan), Liaoning, Northeast China. Human and Ecological Risk Assessment: An International Journal, 1-20. 
Xu, D. M., Yan, B., Chen, T., Lei, C., Lin, H. Z., Xiao, X. M., 2017. Contaminant characteristics and environmental risk assessment of heavy metals in the paddy soils from lead $(\mathrm{Pb})$-zinc $(\mathrm{Zn})$ mining areas in Guangdong Province, South China. Environ Sci Pollut R, 24(31):24387-24399.

Xu, M., Wang, R., Yang, X., Yang, H., 2020. Spatial distribution and ecological risk assessment of heavy metal pollution in surface sediments from shallow lakes in East China. Journal of Geochemical Exploration, p.106490.

Yang, Q., Li, Z., Lu, X., Duan, Q., Huang, L., Bi, J., 2018. A review of soil heavy metal pollution from industrial and agricultural regions in China: pollution and risk assessment. Sci. Total Environ. 642, 690700.

Yang, P., Drohan, P.J., Yang, M., Li, H., 2020. Spatial variability of heavy metal ecological risk in urban soils from Linfen, China. Catena, 190, p.104554.

Zhao, L., Xu, Y., Hou, H., Shangguan, Y., Li, F., 2014. Source identification and health risk assessment of metals in urban soils around the Tanggu chemical industrial district, Tianjin, China. Sci Total Environ 468:654-662.

Zheng, N., Liu, J., Wang, Q. and Liang, Z., 2010. Health risk assessment of heavy metal exposure to street dust in the zinc smelting district, Northeast of China. Science of the Total Environment, 408(4), pp.726733. 
Figures

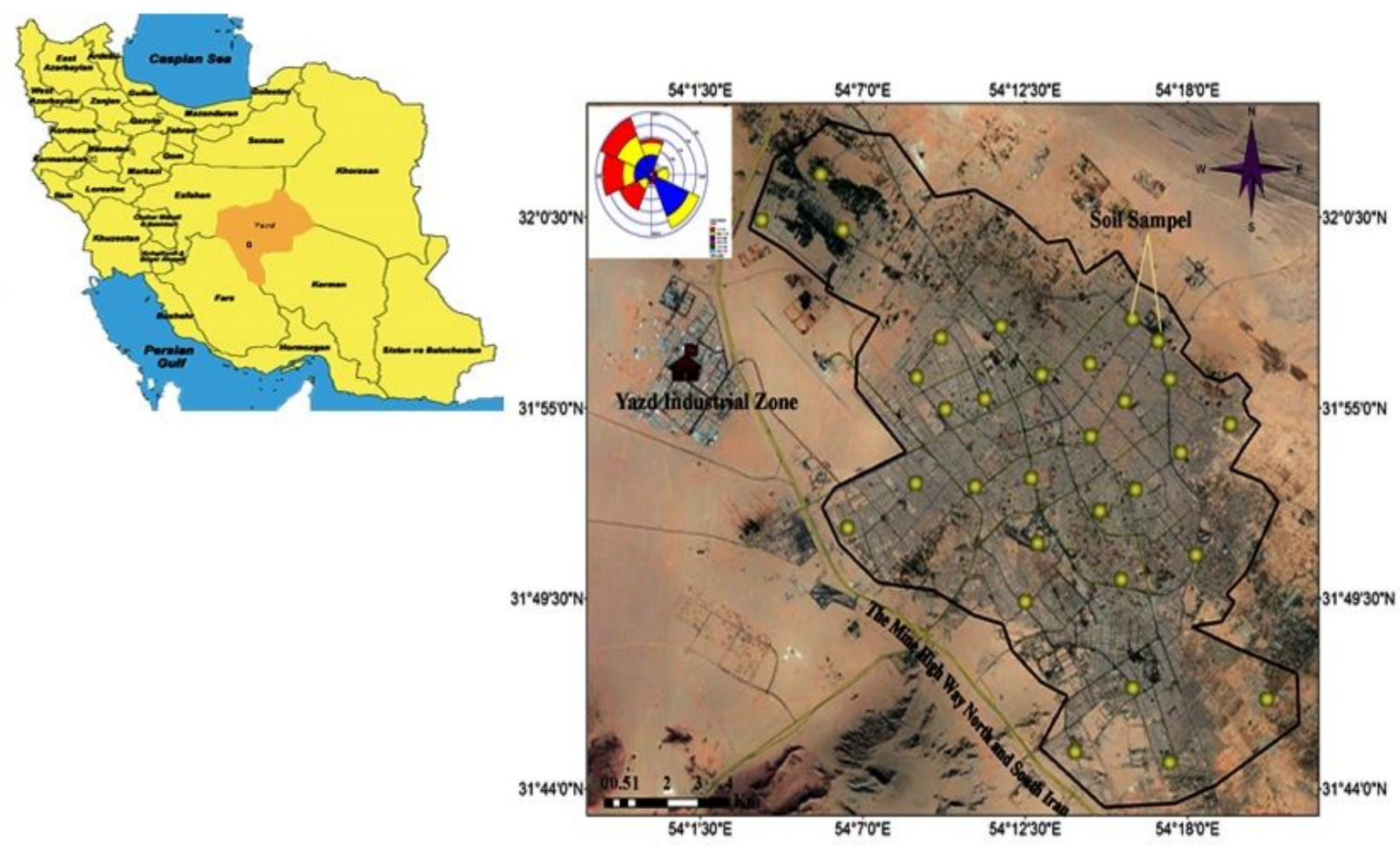

Figure 1

Location of sampling points and Yazd city in Iran 

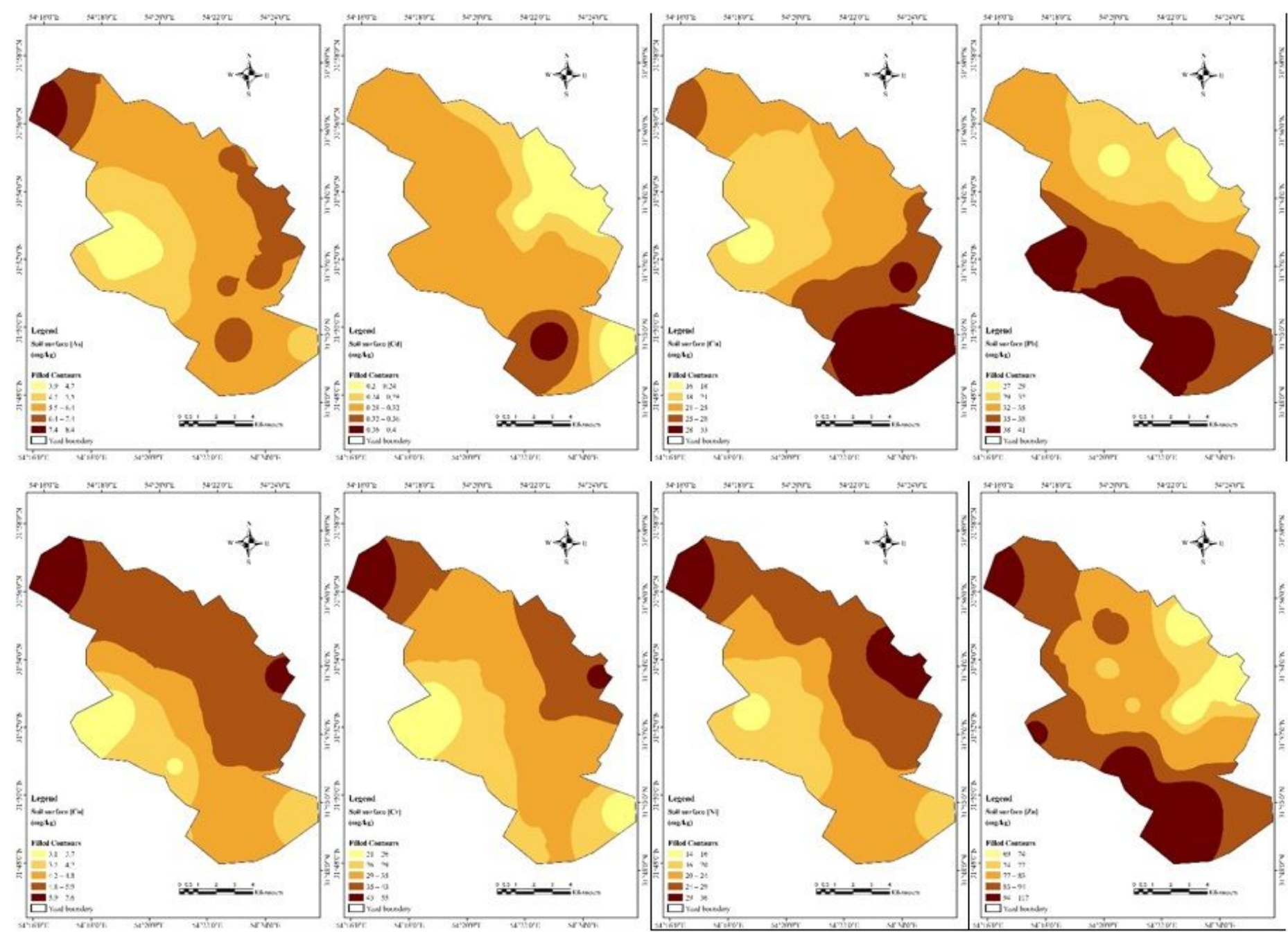

Figure 2

Spatial distribution of the concentration of toxic elements in the urban soil of Yazd city 

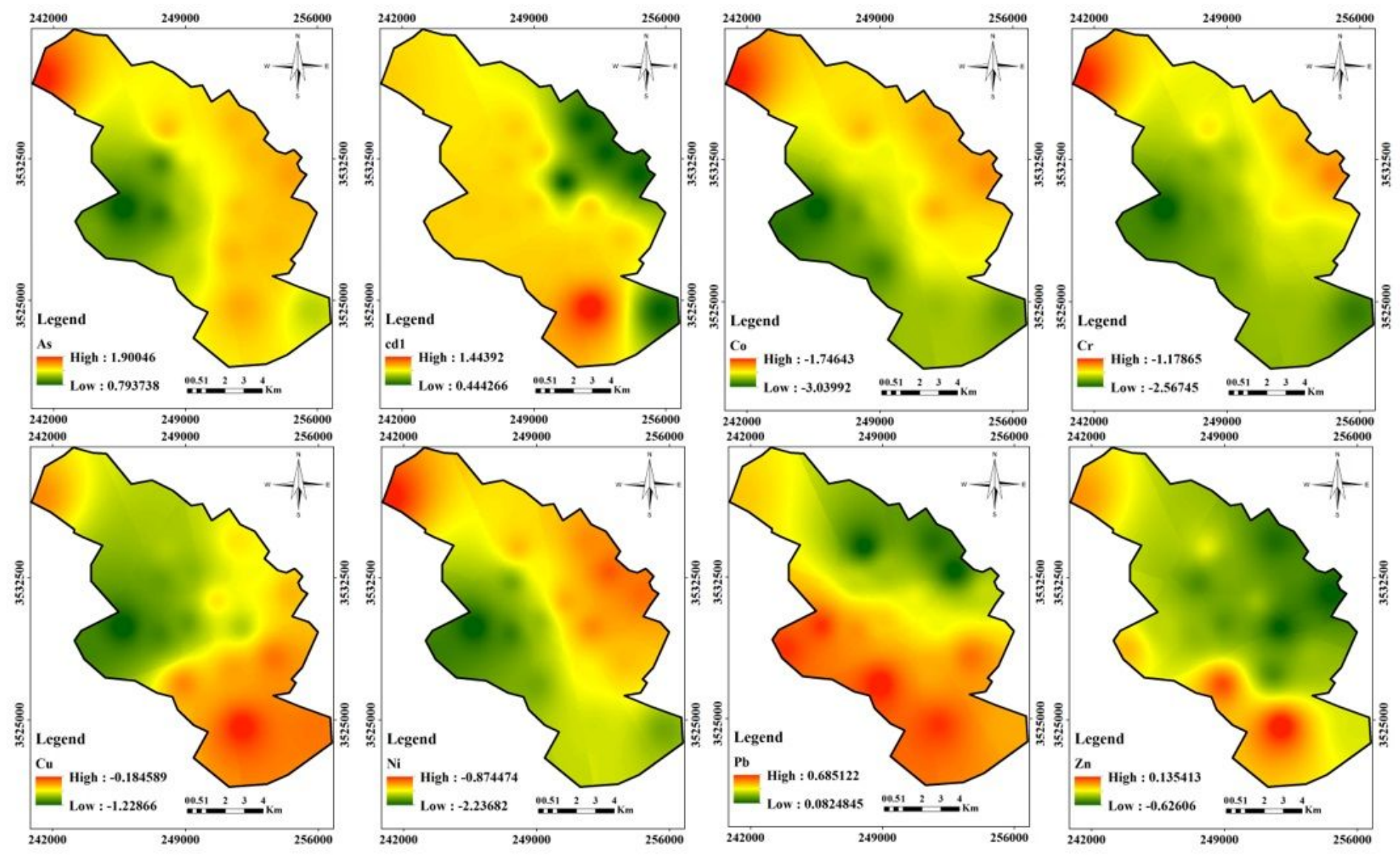

Figure 3

Geo-accumulation index (Igeo) values of toxic metals in the urban soils of Yazd City.



Figure 4 
Box-plots of PI for toxic metals in the urban soil samples of Yazd.



\section{Figure 5}

The pollution index $(\mathrm{PI})$ characteristics of toxic metals in the urban soils of Yazd.



Figure 6

Box-plots of IPI, LPI, INPI and Cd indexes for toxic metals in the urban soil samples of Yazd. 

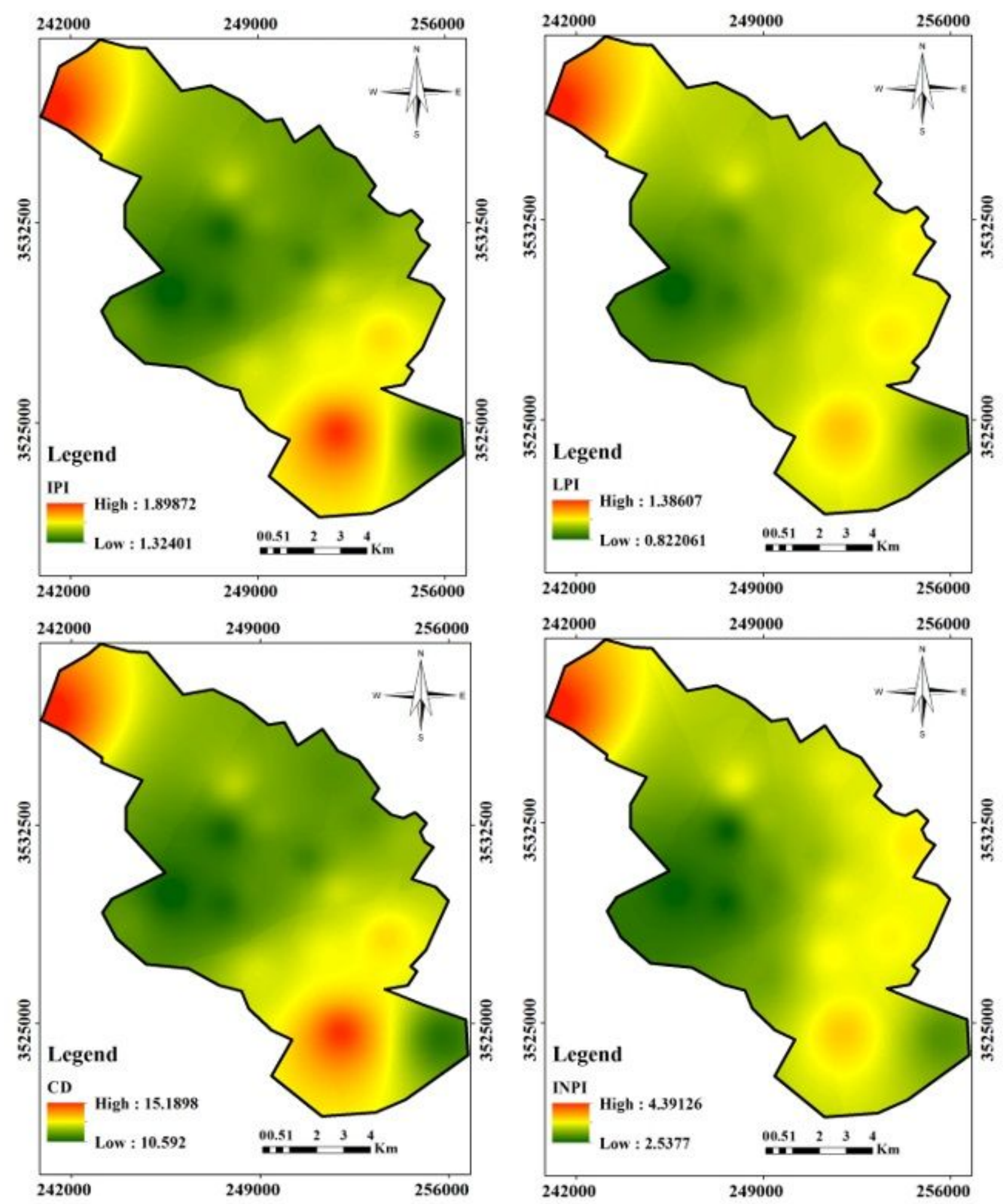

Figure 7

Spatial distribution of the pollution indexes IPI, LPI, INPI and CD in the urban soil of Yazd city 
Rescaled Distance Cluster Combine

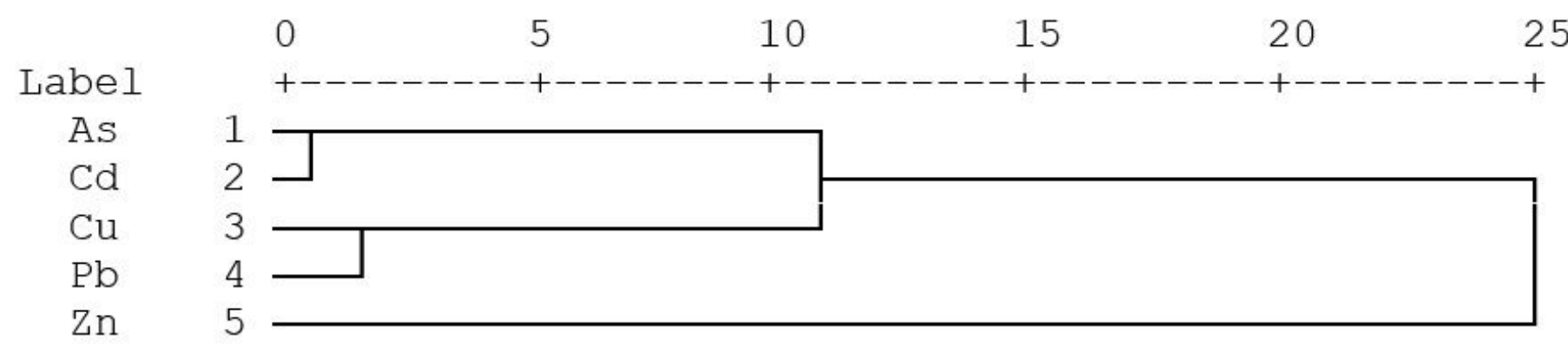

Figure 8

Dendrogram of hierarchical cluster analysis for toxic metals from Yazd city. 